\title{
Long-term changes of water physicochemical conditions and benthic microbial processes in a small lake associated with land use in the catchment
}

\author{
Alina Krevš* , Alè Kučinskienė and Levonas Manusadžianas \\ Nature Research Centre, Institute of Botany, Žaliuju Ežeru 49, Vilnius 08648, Lithuania
}

Received: 25 June 2019 / Accepted: 7 October 2019

\begin{abstract}
Changes in land use in the catchments and areas near the shorelines of lakes may have undesirable consequences for the functioning of lake ecosystems. We studied temporal changes in physicochemical parameters and benthic microbial processes within the small Lake Gulbinas (Lithuania) in relation to the type of land use in the catchment. We compared the period when agriculture activity decreased and increased urban development commenced (2001-2002, transition period) with periods of intense urban land use (2007, 2014-2015). The results were compared to reference data from earlier agricultural periods (1962, 1987-1989). The highest nutrient concentrations in the water were observed during the period of agriculture activity, while increased phosphate concentrations in the near-bottom water and increased organic carbon content and microbial activity in the lake sediments were observed during the period of intense urban land use. Throughout the latter period, anaerobic mineralization of organic carbon via sulfate reduction in bottom sediments was significantly higher than that during the transition period. The intensification of benthic sulfate reduction led to sulfide increase and, thus, to a higher phosphate mobility re-fertilizing the water. Our study suggests that, with a shift of land usage in catchment areas from agricultural to urban, increasing sedimentary organic carbon and its intensive anaerobic mineralization may stimulate internal eutrophication of small lakes.
\end{abstract}

Keywords: Nutrients / benthic microorganisms / lake / catchment

\begin{abstract}
Résumé - Changements à long terme des conditions physico-chimiques de l'eau et des processus microbiens benthiques dans un petit lac associés à l'utilisation des terres dans le bassin hydrographique. Les changements dans l'utilisation des terres dans les bassins versants et les zones situées près des rives des lacs peuvent avoir des conséquences indésirables sur le fonctionnement des écosystèmes lacustres. Nous avons étudié les changements temporels des paramètres physico-chimiques et des processus microbiens benthiques dans le petit lac Gulbinas (Lituanie) en fonction du type d'utilisation des terres dans le bassin versant. Nous avons comparé la période au cours de laquelle l'activité agricole a diminué et le développement urbain s'est intensifié (2001-2002, période de transition) avec les périodes d'utilisation urbaine intensive des terres $(2007,2014-2015)$. Les résultats ont été comparés aux données de référence des périodes agricoles précédentes (1962, 1987-1989). Les concentrations d'éléments nutritifs dans l'eau les plus élevées ont été observées pendant la période d'activité agricole, tandis que les concentrations accrues de phosphate dans l'eau près du fond et la teneur en carbone organique et l'activité microbienne dans les sédiments lacustres ont été observées pendant la période d'utilisation urbaine intensive des terres. Tout au long de cette dernière période, la minéralisation anaérobie du carbone organique par réduction des sulfates dans les sédiments de fond a été beaucoup plus importante que pendant la période de transition. L'intensification de la réduction des sulfates benthiques a entraîné une augmentation des sulfures et, par conséquent, une plus grande mobilité des phosphates, ce qui a entraîné une nouvelle fertilisation de l'eau. Notre étude suggère qu'avec le déplacement de l'utilisation des terres dans les bassins versants de l'agriculture vers des zones urbaines, l'augmentation du carbone organique sédimentaire et sa minéralisation anaérobie intensive peuvent stimuler l'eutrophisation interne des petits lacs.
\end{abstract}

Mots-clés : Nutriments / microorganismes benthiques / lac / bassin versant

\footnotetext{
*Corresponding author: alinakrevs@gmail.com
} 


\section{Introduction}

In recent decades, a worldwide intensification of human impacts has accelerated changes in lake ecosystem processes. Water eutrophication is such a case that promotes the growth of phytoplankton and enhances the content of organic matter in a water body (Smith, 2003; Conley et al., 2009). The nutrient levels of many lakes and rivers have increased dramatically over the past 50 years in response to increased discharges of domestic waste and non-point pollution originating from agricultural practices and urban development (Jeppesen et al., 1999; Mainstone and Parr, 2002; Yang et al., 2008). Organic matter that is produced in the process of photosynthesis and/or enters the water body from the surrounding environment settles on the lake bottom, either in the littoral or profundal zone, and undergoes aerobic and anaerobic microbial decomposition. Released nutrients and reduced compounds (hydrogen sulfide, methane and others) may be recycled back into the water (Megonigal et al., 2004; Nowlin et al., 2005; Dzyuban, 2007). The profundal zone acts as a fundamental source of environment information on the lake history as the sediments accumulate contaminants, e.g. excessive quantities of nutrients, pesticides, remains of invertebrates, diatoms and certain bacteria which are deposited in the lake sediments by chemical precipitation or the settling of particulate matter and exchange between the bottom and overlying waters (Margaritora et al., 2003). Environmental parameters and organisms living in the profundal zone (their richness, along with the presence and abundance of bioindicators) reflect the current ecological conditions and can provide an integrated synthesis of these disturbance factors, revealing both short and long-term changes in ecological quality, and so complete a picture of quality conditions of both sediments and overlying waters in a lake (Rosenberg and Resh, 1993; Bazzanti et al., 1993; Lang and Lods-Croset, 1997). Furthermore, integrated data between biological and physicochemical parameters are necessary for both the evaluation of the present environmental quality of the lake and for the possible future assessment of its trophic status (Margaritora et al., 2003).

Eutrophication constitutes a serious threat to many European lakes (Søndergaard et al., 2007). In Lithuania, there are more than 6000 lakes of natural origin (glacial, karst, fluvial), occupying an area equating to about $1.5 \%$ of the whole territory. Small lakes ( $<50$ ha) predominate, with only 14 lakes exceeding 1000 ha (Kilkus, 2005). The depth and area of most of the lakes have considerably decreased due to sedimentation during their long period of existence (about ten thousand years). As a result, the layer of bottom sediments is now $5-10 \mathrm{~m}$ thick in most lakes, and up to $20 \mathrm{~m}$ thick in some lakes (Garunkštis, 1988). The majority of shallow lakes (mean depth $<3 \mathrm{~m}$ ) are categorized as eutrophic, while deep lakes (mean depth $>15 \mathrm{~m}$ ), exposed to lower anthropogenic load, and "young" lakes, formed by current geomorphologic processes (e.g., karst), are not so nutritious (Kilkus, 2005; Daubariene and Valiuškevičius, 2009). Increased agricultural activity in the middle of the 20th century and recreation and urbanization at the beginning of the 21 st century have resulted in a higher load of nutrients and intensified eutrophication processes in most Lithuanian lakes (Linkeviciene et al., 2004).
There are many small shallow (mean depth $<3 \mathrm{~m}$ ) and medium-depth (mean depth 3-15 m) lakes of glacial origin in the vicinity of Vilnius, the capital of Lithuania. This study focuses on Lake Gulbinas, belonging to a cluster of so-called Green Lakes. In 1964, in order to preserve the unique landscape and biodiversity value, the Green Lakes acquired the status of a landscape reserve (Kilkus, 1986). The reserve was upgraded to the Green Lakes Landscape Preserve in 1992 covering an area of 331 ha in close vicinity to Vilnius (http://www.vilniusgo.lt/2016/ $11 / 05$ /zalieji-ezerai). Due to endangered species and natural habitats, part of the Green Lakes Landscape Preserve is included in the Natura 2000 network of protected areas of European importance (http://ec.europa.eu/environment/nature/ natura2000). Despite these conservation efforts, the catchment area of Lake Gulbinas is still under strong anthropogenic impact. Worldwide, loadings caused by human activities induce quantitative changes in limnetic systems of lake areas and accelerate their eutrophication (Correl, 1997; Moore et al., 2003). Accumulation of organic matter, leading to increasing sedimentation and silt deposition in shallow lakes, are among the negative effects of eutrophication (Margaritora et al., 2005; Kubera and Donderski, 2017). Ongoing environmental changes in water ecosystems can be evaluated through long-term studies that may predict further changes or identify means to mitigate the impact of human activities (Shadrin et al., 2016). However, there are virtually no long-term ecological studies focussing on small lakes that are subject to the influence of changing types and extents of human actions in their catchment areas.

This study was aimed at assessing the long-term changes of water physicochemical conditions and profundal benthic microbial processes in Lake Gulbinas (Lithuania) during different land use periods in the catchment. Based on the relatively large ratio of catchment vs lake area, we expected that a change of dominant land-use form over decades would have implications on lake ecosystem processes and environmental conditions. We put forward a hypothesis that, following the input of nitrogen and phosphorus during the agricultural period, the growing lake trophy and increasing leakage of terrigenous material from construction sites during urban land use would cause an increase in sedimentary organic matter and intensify benthic microbial processes. To test our hypothesis, (1) we compared the physicochemical conditions of the lake, benthic bacterial numbers and microbial processes (oxygen consumption, inorganic carbon emission and sulfate reduction) between the two periods of different land use in the lake catchment area, i.e. during the period of decreasing agricultural activity and beginning of urban development (the transition period, 2001-2002) and the period of urban land use (2007 and 2014-2015); and (2) we compared the environmental conditions of the lake with those reported during the periods in which agriculture dominated in the catchment area, i.e. 1962, 1987-1989 (Klimkaite, 1963; Studies of Lithuanian lakes..., 1989; Kavaliauskiené, 1996).

\section{Materials and methods}

\subsection{Study area and sampling strategy}

Lake Gulbinas is the second largest lake within the group of Green Lakes and is situated on the right bank of the Neris 


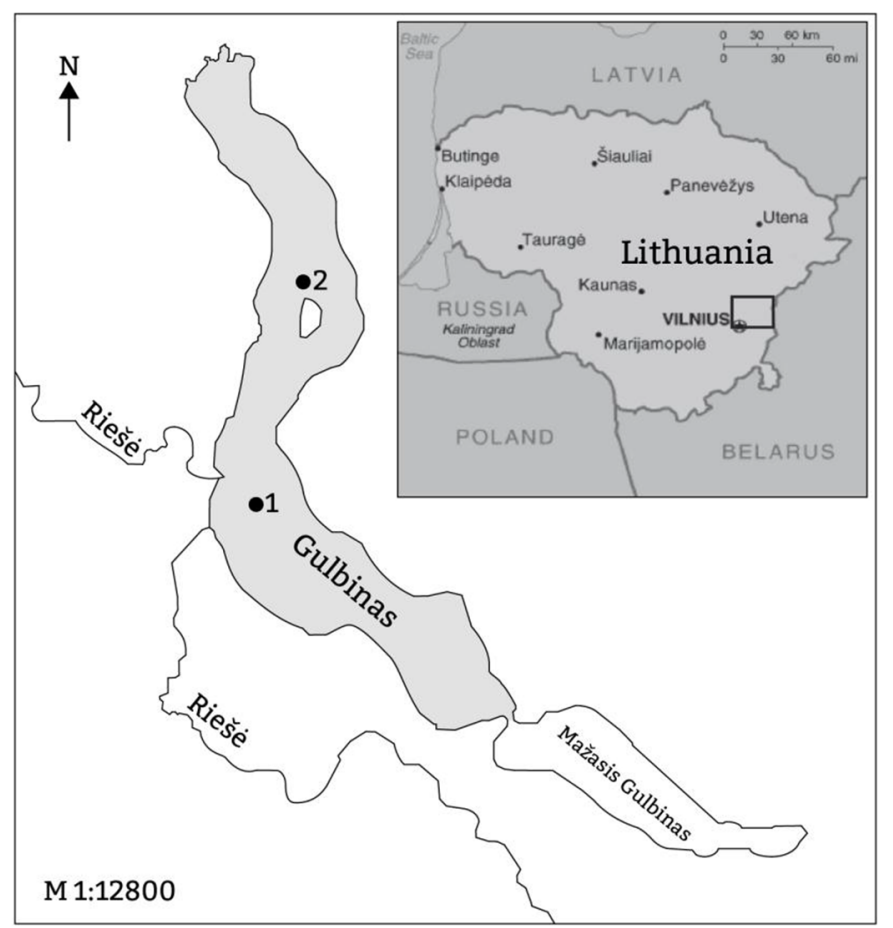

Fig. 1. Location of sampling sites in Lake Gulbinas: 1-shallow part, 2-deep part.

Table 1. General characteristics of Lake Gulbinas (Lake Passport Nr.17/VV-0010, 2003; Kilkus, Bernatonis, 2003).

\section{Parameters}

\begin{tabular}{ll} 
Location coordinates & $54^{\circ} 47^{\prime} 45^{\prime \prime} \mathrm{N} 25^{\circ} 18^{\prime} 05^{\prime \prime} \mathrm{E}$ \\
Catchment area, $\mathrm{km}^{2}$ & 78.4 \\
Lake surface area, $\mathrm{km}^{2}$ & 0.37 \\
Catchment area/lake area ratio & 212 \\
Maximum depth, m & 11.8 \\
Mean depth, m & 4.2 \\
Volume, $10^{6} \mathrm{~m}^{3}$ & 1.5 \\
Length of shore line, $\mathrm{km}$ & 4.9 \\
\hline
\end{tabular}

River in Verkiai Regional Park in the northern suburbs of Vilnius (Fig. 1). The morphometric indices of the lake are shown in Table 1. Based on the classification of Lithuanian lakes by their average depth (Daubarienè and Valiuškevičius, 2009), it is assigned as a medium-depth lake. The banks of the lake are mainly dry, steep with a relative height up to $20 \mathrm{~m}$ and are surrounded by trees. The relatively large ratio of catchment vs lake area indirectly indicates the importance of changes in the catchment area to the flow of allochtonic matter into the lake. The amount of nutrients in Lake Gulbinas is partly controlled by the Rieše stream, which runs through fields and urbanized areas before flowing into the lake. The mean discharge volumes of the stream inflow and outflow are 0.42 and $0.47 \mathrm{~m}^{3} \times \mathrm{s}^{-1}$ respectively and the annual water exchange rate of the lake is 0.45 (Studies of Lithuanian Lakes..., 1989). The lake is also fed by groundwater. Lake Gulbinas is of glacial
Table 2. Land use in the catchment of Lake Gulbinas in 1987 (Studies of Lithuanian Lakes ..., 1989), 2002 (Lake passport Nr.17/VV-0010, 2003) and 2015 (www.geoportal.1t).

\begin{tabular}{llll}
\hline Catchment land use/years & \multicolumn{3}{c}{ Area, $\mathrm{km}^{2}(\%)$} \\
\cline { 2 - 4 } & 1987 & 2002 & 2015 \\
\hline Cultivated field & $36.7(47)$ & $17.3(22)$ & $0.8(1)$ \\
Uncultivated field & $17.3(22)$ & $12.8(16.4)$ & $16.2(21)$ \\
Urban & $0.5(0.6)$ & $28.5(36.3)$ & $45.0(57)$ \\
Forestry & $21.7(27.7)$ & $17.9(22.9)$ & $15.2(19.5)$ \\
Swamp & $2.2(2.7)$ & $1.9(2.4)$ & $1.2(1.5)$ \\
Total area & $78.4(100)$ & $78.4(100)$ & $78.4(100)$ \\
\hline
\end{tabular}

origin, but its pit was transformed near the mouth of the Rieše stream due to intensive sedimentation of terrigenous particles in the past. Resulting from sedimentation, a shallow $(4 \mathrm{~m})$ flow-through central area has divided the lake into two more stable and relatively deep pits, located in the north $(11.8 \mathrm{~m})$ and south $(9.5 \mathrm{~m})$ parts of the lake (Kilkus and Bernatonis, 2003). Data on land use changes in the catchment of Lake Gulbinas are presented in Table 2. During intensive agricultural activity in the 1950s-1980s, large quantities of allochthonous matter entered the lake from agricultural areas, especially from cultivated fields (Kilkus, 1986). In 1987, the use of mineral and organic fertilizers in the catchment area of Lake Gulbinas reached averages of $282 \mathrm{~kg} / \mathrm{ha}$ and $709 \mathrm{~kg} / \mathrm{ha}$ respectively (Studies of Lithuanian Lakes..., 1989). In the 1990s, agricultural activity decreased dramatically in the catchment, while recreational use of the landscape increased at the same time. This was effectively the transitional period between agricultural use and the start of urbanization, as urban development began in the catchment from the beginning of the 21st century (Linkeviciene et al., 2004). Since 2007, residential construction has increased dramatically not only in the catchment, but also near the shoreline of the lake.

Physicochemical parameters of water (transparency, temperature, $\mathrm{pH}$, dissolved oxygen and nutrients) were measured in the deep northern $(9 \mathrm{~m})$ part of the lake and in the shallow (4 m) part in the last ten days of May, August and September in 2001-2002, 2007 and 2014-2015 (Fig. 1). Lake sediments $(0-5 \mathrm{~cm})$ for the analyses of chemical parameters (total organic carbon, sulfates, hydrogen sulfide and acidsoluble sulfides), bacterial abundance and microbial activity (expressed as the rate of organic carbon mineralization and sulfate reduction) were sampled in two parts of the lake in August 2001-2002 and 2007, and in the spring-autumn period in 2014-2015. Surface and near-bottom water in the shallow part and in water at 1-m intervals in the deepest part were sampled using a 2 L Ruttner sampler. Sediment samples were taken using a metal tube sampler. Sediment cores were taken in triplicate at each sampling site. During sample collection, a global positioning system (GPS) was used to locate the sites.

\subsection{Physicochemical analysis}

Water temperature, $\mathrm{pH}$ and transparency were measured in situ with a portable universal multiLine F/Set-3 meter and 
Secchi disk; dissolved oxygen concentration was determined with an oxygen meter (Eutech Instruments). Nutrients (phosphorus, nitrogen, dissolved organic carbon) and biochemical oxygen demand $\left(\mathrm{BOD}_{7}\right)$ analyses of upper and nearbottom water samples were performed in a certified analytical laboratory "JSC Water Investigations". Inorganic phosphate (IP) was assessed via molybdate ascorbic acid method after digestion with sulfuric acid (ISO 6878). The total phosphorus (TP) concentration was measured using persulfate- $\mathrm{H}_{2} \mathrm{SO}_{4}$ digestion and molybdate ascorbic acid methods (ISO 15681-2). For inorganic nitrogen (IN) analysis, nitrate and nitrite were determined by Ion Chromatography (ISO 10304-1), while ammonium by manual spectrometric method (ISO 7150-1). The total nitrogen (TN) was determined using potassium persulfate- $\mathrm{K}_{2} \mathrm{~S}_{2} \mathrm{O}_{8}$ digestion following $\mathrm{Cd}-\mathrm{Cu}$ reduction to $\mathrm{NO}_{2}$ (ISO 11905-1), while dissolved organic carbon (DOC) according to ISO 8245. Hydrogen sulfide in the water column was analyzed with colorimetric test (Microquant Merck). Hydrogen sulfide and acid-soluble sulfides $\left(\mathrm{H}_{2} \mathrm{~S}+\mathrm{HS}^{-}\right)$in bottom sediments were determined according to the method described by Volkov and Zhabina (1980). Bottom sediment samples were taken in $100 \mathrm{ml}$ flaks in duplicate and fixed with aquatic $\mathrm{ZnSO}_{4}+\mathrm{Na}_{2} \mathrm{CO}_{3}$ solutions. After treatment with gaseous nitrogen, the sulfides were subject to an alkaline $\mathrm{CdSO}_{4}$ solution. Total amounts of hydrogen sulfides and acid soluble sulfides were calculated after titration with sodium thiosulfate.

\subsection{Bacteria}

For the investigation of benthic bacteria, $1 \mathrm{~g}$ sediments were placed in flasks with $100 \mathrm{~mL}$ of autoclave sterilized water and sonicated in bath (Kraintek, Slovakia) for $4 \mathrm{~min}$ at $38 \mathrm{kHz}$ and then were extracted on a rotary shaker (Certomat ${ }^{\circledR}$ UHK$50)$ by shaking $(200 \mathrm{rpm})$ for $15-20 \mathrm{~min}$. The total number of benthic bacteria (TNB) were estimated by epifluorescence microscopy after 4',6-diamidino-2-phenylindole (DAPI) staining on $0.2 \mu \mathrm{m}$ black filters (Millipore, Bedford, MA) (Porter and Feig, 1980). At least 200 bacterial cells in 20 fields were counted at 1000 magnification using a Nikon Eclipse (Japan) epifluorescence microscope. Bacterial abundance was analyzed in three sub-replicates and calculated per gram of fresh weight of sediment. To account for sulfate reducing bacteria (SRB), samples were inoculated into lactate-supplemented Postgate medium (Postgate, 1984). The samples to be tested were prepared in a 10 -fold dilution series of liquid media, and then $1 \mathrm{~mL}$ aliquots of each dilution were inoculated into triplicate agar medium tubes for incubation. After 3-4 weeks, black tubes were counted. The degree of blackening through the medium is directly proportional to the amount of SRB expressed as colonies formation units per $\mathrm{g}$ of sediments $\left(10 \times \mathrm{CFU} \mathrm{g}^{-1}\right)$.

\subsection{Microbial processes}

The mineralization rate of organic carbon (OC) in bottom sediments was determined based on the respiratory activity of benthic aerobic and anaerobic communities, and measured from the amounts of consumed oxygen and released inorganic carbon in hermetically sealed tubes with sediment core and near-bottom water (Kuznetsov and Dubinina, 1989). Plastic tubes (diameter $5 \mathrm{~cm}$ and length $40 \mathrm{~cm}$ ) were gently pushed $0-5 \mathrm{~cm}$ deep into undisturbed sediments and sealed with a stopper from below. Duplicate tubes with sediments and two tubes without sediments were carefully filled with near-bottom water and hermetically sealed with caps, while ensuring no air bubbles were left in the tubes. The tubes with samples were placed in dark bags and incubated in containers filled with near-bottom water for $24 \mathrm{~h}$ at a temperature corresponding to that at the sampling site. Oxygen consumption by the sediments $\left(\mathrm{mg} \mathrm{O}_{2} \mathrm{~m}^{2} \mathrm{~d}^{-1}\right)$ and inorganic carbon emission from them $\left(\mathrm{mg} \mathrm{C} \mathrm{m}^{2} \mathrm{~d}^{-1}\right.$ ) were estimated by the differences in their amount in the water between samples with and without sediments. The percentage contribution of aerobic and anaerobic processes to carbon mineralization was evaluated after calculating the difference between the total inorganic carbon emission and emission by aerobic respiration. For the evaluation of inorganic carbon emission by aerobic respiration, the values of consumed oxygen were converted to carbon by the weight ratio 0.44 at a respiratory coefficient of 0.85 (Kuznetsov and Dubinina, 1989). The sulfate reduction rate (SR) was ascertained using a $\mathrm{Na}_{2}{ }^{35} \mathrm{SO}_{4}$ tracer technique (Sorokin, 1999). Bottom sediment samples were placed in duplicate $20 \mathrm{~mL}$ glass tubes and hermetically sealed with rubber stoppers. $\mathrm{Na}_{2}{ }^{35} \mathrm{SO}_{4}$ solution (Amersham Pharmacia Biotech) of at least $2-3 \times 10^{6}$ impulses (imp) $/ 0.1 \mathrm{~mL} \mathrm{~min}$ ) radioactivity was injected into the samples by syringe with a long needle. Glass tubes with bottom sediment samples were incubated for $24 \mathrm{~h}$ in dark bags placed in hermetic impact resistant thermos bottles filled with bottom water and submerged in the near-bottom water layer to maintain them at the same temperature as the surroundings. The samples after the incubation in situ were fixed with $2 \mathrm{~mL}$ of $20 \mathrm{mM}$ $\mathrm{Na}_{2} \mathrm{MoO}_{4} \times 2 \mathrm{H}_{2} \mathrm{O}$ solution. In the laboratory, the samples were acidified, and hydrogen sulfide was distilled into alkaline $0.05 \mathrm{~N} \mathrm{KMnO}_{4}$. The labeled sulfides were converted to sulfates, and their radioactivity (as $\mathrm{BaSO}_{4}$ precipitates) was measured on filters $(0.2 \mu \mathrm{m}$, Millipore $)$ placed in vials containing $5 \mathrm{~mL}$ of the scintillation cocktail Opti Phase Hi Safe (Wallac Scintilation products). Radioactivity was determined using a scintillation counter.

\subsection{Statistical analysis}

The normality and homogeneity of variance were checked using Shapiro-Wilk's test and the Levene test, respectively. As not all water physicochemical parameter data showed normal distribution, we used a non-parametric Kruskal-Wallis test for differences between these data sets. Since all the benthic chemical and microbial data met ANOVA assumptions, the differences in these data sets between study periods were tested with Tukey post-hoc test $(p \leq 0.05)$. The statistical analysis was carried out using the software PASW Statistics 18.0 (Predictive Analytics Software, IBM).

\section{Results}

\subsection{Water physicochemical parameters}

During urbanization in the catchment area (2007 and 2014-2015), water transparency in Lake Gulbinas was 
Table 3. Temperature, dissolved oxygen and hydrogen sulfide concentrations in the water of Lake Gulbinas during the different study periods (mean values \pm standard deviation of data from May, August and September). Asterisks indicate significant differences (Kruskal-Wallis test, $p \leq 0.05$ ) in each water parameter between two study periods, urban and agriculture.

\begin{tabular}{|c|c|c|c|c|c|c|}
\hline \multirow[t]{3}{*}{ Parameter } & \multirow[t]{3}{*}{ Sampling site } & \multirow[t]{3}{*}{ Depth (m) } & \multicolumn{4}{|c|}{ Period, years } \\
\hline & & & \multirow{2}{*}{$\begin{array}{l}\text { Agriculture } \\
1962\end{array}$} & \multirow{2}{*}{$\begin{array}{l}\text { Transitional } \\
2001-2002\end{array}$} & \multicolumn{2}{|c|}{ Urban } \\
\hline & & & & & 2007 & 2014-2015 \\
\hline \multirow[t]{5}{*}{ Temperature $\left({ }^{\circ} \mathrm{C}\right)$} & \multirow[t]{2}{*}{ Shallow part } & 0.5 & $15.0 \pm 2.3$ & $18.6 \pm 3.5$ & $18.9 \pm 2.6$ & $20.2 \pm 2.4^{*}$ \\
\hline & & 4.0 & $14.4 \pm 2.2$ & $16.3 \pm 2.2$ & $12.3 \pm 2.3$ & $14.1 \pm 1.2$ \\
\hline & \multirow[t]{3}{*}{ Deep part } & $0-2.0$ & $15.3 \pm 0.2$ & $17.7 \pm 0.2$ & $18.7 \pm 0.4^{*}$ & $18 \pm 0.5^{*}$ \\
\hline & & $3.0-5.0$ & $13.3 \pm 0.7$ & $15.0 \pm 0.6$ & $14.8 \pm 1.0$ & $14 \pm 0.5$ \\
\hline & & $6.0-9.0$ & $9.9 \pm 1.2$ & $9.6 \pm 0.1$ & $9.4 \pm 1.0$ & $9.5 \pm 0.5$ \\
\hline \multirow[t]{5}{*}{ Oxygen $\left(\mathrm{mg} \mathrm{L}^{-1}\right)$} & \multirow[t]{2}{*}{ Shallow part } & 0.5 & $10.0 \pm 0.9$ & $9.8 \pm 1.1$ & $10.9 \pm 0.4$ & $10.0 \pm 0.2$ \\
\hline & & 4.0 & $9.2 \pm 0$ & $6.4 \pm 1.6$ & $1.0 \pm 0.9^{*}$ & $1.5 \pm 1.1^{*}$ \\
\hline & \multirow[t]{3}{*}{ Deep part } & $0-2.0$ & $9.6 \pm 0.1$ & $10.3 \pm 0.1$ & $9.8 \pm 1.2$ & $9.0 \pm 0.5$ \\
\hline & & $3.0-5.0$ & $8.6 \pm 0.5$ & $6.8 \pm 2.6$ & $3.6 \pm 2.0^{*}$ & $3.5 \pm 1.0^{*}$ \\
\hline & & $6.0-9.0$ & $3.5 \pm 2.2$ & 0 & $0^{*}$ & $0^{*}$ \\
\hline \multirow{3}{*}{$\begin{array}{l}\text { Hydrogen sulfide } \\
\left(\mathrm{mg} \mathrm{L}^{-1}\right)\end{array}$} & \multirow[t]{3}{*}{ Deep part } & $0-3.0$ & - & 0 & 0 & 0 \\
\hline & & $4.0-5.0$ & - & 0 & $0.2 \pm 0.1$ & $0.2 \pm 0.1$ \\
\hline & & $6.0-9.0$ & - & $0.4 \pm 0.2$ & $1.2 \pm 0.5$ & $0.5 \pm 0.1$ \\
\hline
\end{tabular}

"-” No data.

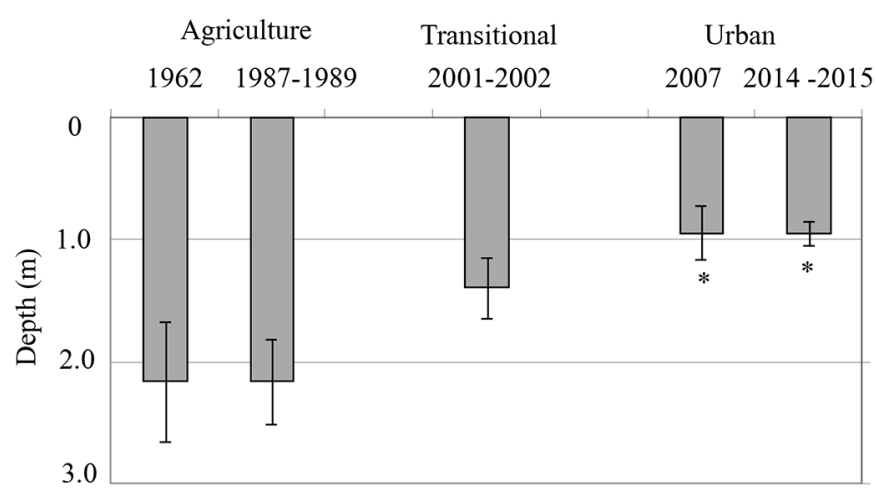

Fig. 2. Water transparency in the different periods of land use in the catchment area of Lake Gulbinas (mean values \pm SD of measurements in the last ten days of May, August and September). Asterisks indicate significant differences (Kruskal-Wallis test, $p \leq 0.05$ ) in water transparency between two study periods, urban (2007, 2014-2015) and agriculture $(1962,1987-1989)$.

significantly lower compared to its values in the periods of agricultural catchment land use in 1962 and 1987-1989 (Fig. 2). The mean temperature in the upper water layer $(0-2 \mathrm{~m})$ in May-September increased if comparing 1962 and 2007-2015 (Tab. 3). The largest differences in the vertical profiles of the temperatures across the different years were found during summer stratification. For example, the thermocline was at 6-8 $\mathrm{m}$ depth in August 1962, while in the urban period (August 2015) it was at around 3-5 $\mathrm{m}$ depth (Fig. 3). An insignificant decrease in the temperature near the bottom was found in the recent period compared with 1962. As for the shallow part of the lake, the difference between the water temperature in the surface and near-bottom layers increased from 2007 (Tab. 3).

Except for the upper water layer $(0-2 \mathrm{~m})$, the mean concentration of dissolved oxygen at all depths in late springearly autumn in the lake significantly differed between the recent and earlier study periods, with an expanding layer without oxygen during the urban period of land use (Tab. 3). In August, in the agricultural period of land use, a depletion of oxygen concentration was registered at a depth of $8 \mathrm{~m}$, while in the urban period the upper boundary of the layer without oxygen had risen to 4-5 m and its deficit (1.3-2.4 $\mathrm{mg} \mathrm{L}^{-1}$ ) was observed even at a depth of $3 \mathrm{~m}$ (Fig. 3). From 2001, hydrogen sulfide accumulated in anaerobic hypolimnion in the deepest part of the lake. In the urban period, the depletion of oxygen in near bottom waters was also observed in the shallow part of the lake throughout the sampling time (Tab. 3).

The $\mathrm{pH}$ in the depth profiles in 1962 was alkaline $(\mathrm{pH}$ 8.2-8.0) and neutral only near the bottom ( $\mathrm{pH} 7.2)$. In the transitional and urban periods of land use, its values in the water layer at $0-2 \mathrm{~m}$ depth ranged between alkaline and weakly alkaline ( $\mathrm{pH}$ 8.7-7.7) and in the thermocline and hypolimnion decreased down to 7.3-7.0.

The highest concentrations of nitrogen and phosphorus in the upper water were measured at the end of agriculture period (1987-1989) and their values significantly decreased during urbanization (Tab. 4). However, within urban land use, TP concentration increased in the near bottom waters, with the highest values (up to $0.2 \mathrm{mg} \mathrm{L}^{-1}$ ) measured in September 2015. In the urban period, an increase in the DOC concentration in the water was also registered, especially labile organic matter near the bottom. Throughout all years of the study, the concentration of nitrogen compounds was about two times and TP more than three times higher in near bottom waters than in the upper layer. 

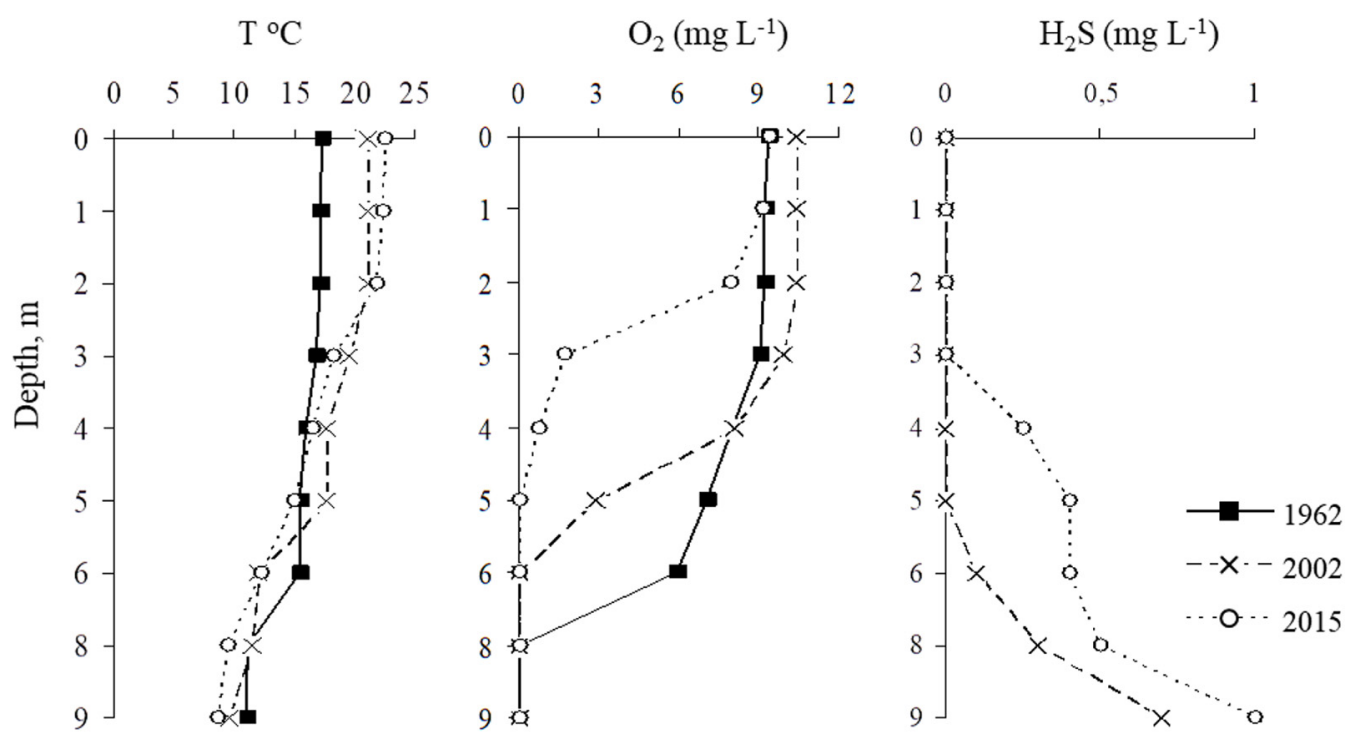

Fig. 3. Depth profiles of temperature $\left(\mathrm{T}^{\circ} \mathrm{C}\right)$, dissolved oxygen $\left(\mathrm{O}_{2}\right)$ and hydrogen sulfide $\left(\mathrm{H}_{2} \mathrm{~S}\right)$ concentration in the water column of Lake Gulbinas in August during the periods of agriculture (1962), transition (2002) and urbanization (2015) in the catchment area.

Table 4. Chemical parameters of the surface and near-bottom water of Lake Gulbinas during the different study periods (mean values \pm SD for May, August and September). Asterisks indicate significant differences (Kruskal-Wallis test, $p \leq 0.05$ ) in each chemical parameter between two study periods, urban (2014-2015) and agriculture (1987-1989).

\begin{tabular}{|c|c|c|c|c|c|}
\hline \multirow[t]{3}{*}{ Parameter } & \multicolumn{5}{|c|}{ Period, years } \\
\hline & \multicolumn{2}{|c|}{ Agriculture } & \multirow{2}{*}{$\begin{array}{l}\text { Transitional } \\
\text { 2001-2002 }\end{array}$} & \multicolumn{2}{|c|}{ Urban } \\
\hline & 1962 & $1987-1989$ & & 2007 & $2014-2015$ \\
\hline \multirow[t]{2}{*}{ Inorganic nitrogen $\left(\mathrm{mg} \mathrm{L}^{-1}\right)$} & $0.4 \pm 0.2$ & $1.3 \pm 0.2$ & $1.3 \pm 0.1$ & $0.8 \pm 0.5$ & $0.7 \pm 0.2^{*}$ \\
\hline & $\overline{0.8 \pm 0.0}$ & $\overline{3.4 \pm 0.3}$ & $\overline{1.8 \pm 0.1}$ & $\overline{2.4 \pm 0.2}$ & $2.3 \pm 0.1^{*}$ \\
\hline \multirow[t]{2}{*}{ Total nitrogen $\left(\mathrm{mg} \mathrm{L}^{-1}\right)$} & - & $2.2 \pm 0.2$ & $1.9 \pm 0.1$ & $1.7 \pm 0.4$ & $1.6 \pm 0.2^{*}$ \\
\hline & & $4.3 \pm 0.2$ & $2.2 \pm 0.2$ & $\overline{3.6 \pm 0.7}$ & $3.5 \pm 0.1^{*}$ \\
\hline \multirow[t]{2}{*}{ Inorganic phosphorus $\left(\mathrm{mg} \mathrm{L}^{-1}\right)$} & - & $\underline{0.03 \pm 0.01}$ & $\underline{0.01 \pm 0.0}$ & $\underline{0.01 \pm 0.0}$ & $0.01 \pm 0.00^{*}$ \\
\hline & & $0.04 \pm 0.01$ & $\overline{0.03 \pm 0.0}$ & $\overline{0.06 \pm 0.0}$ & $0.07 \pm 0.01^{*}$ \\
\hline \multirow[t]{2}{*}{ Total phosphorus (mg L ${ }^{-1}$ ) } & - & $0.06 \pm 0.00$ & $0.05 \pm 0.04$ & $0.03 \pm 0.01$ & $0.03 \pm 0.01^{*}$ \\
\hline & & $\overline{0.08 \pm 0.00}$ & $\overline{0.06 \pm 0.01}$ & $\overline{0.09 \pm 0.02}$ & $0.1 \pm 0.00^{*}$ \\
\hline \multirow[t]{2}{*}{ Dissolved organic carbon $\left(\mathrm{mg} \mathrm{L}^{-1}\right)$} & $9.6 \pm 3.5$ & $9.4 \pm 1.0$ & $10.5 \pm 1.3$ & $10.4 \pm 1.6$ & $10.3 \pm 0.2$ \\
\hline & $\overline{9.8 \pm 1.9}$ & $\overline{9.5 \pm 1.4}$ & $\overline{10.5 \pm 1.0}$ & $\overline{10.8 \pm 0.4}$ & $\overline{10.1 \pm 0.5}$ \\
\hline \multirow{2}{*}{ Biochemical oxygen demand $\left(\mathrm{mg} \mathrm{O}_{2} \mathrm{~L}^{-1}\right)$} & - & $4.8 \pm 0.1$ & $5.7 \pm 0.1$ & $7.5 \pm 0.9$ & $6.8 \pm 0.4^{*}$ \\
\hline & & $\overline{4.3 \pm 0.2}$ & $\overline{4.8 \pm 0.0}$ & $\overline{7.4 \pm 1.0}$ & $9.4 \pm 0.5^{*}$ \\
\hline
\end{tabular}

“-” No data.

\subsection{Bottom sediment chemical parameters and microbial processes}

The highest concentration of sedimentary OC in the lake was found during the urban land use period (Tab. 5). The concentration of hydrogen sulfide and acid soluble sulfides in bottom sediments of both parts of the lake were significantly higher during urban land use than in the transitional period, while sulfate concentration was not significantly affected by land use change.

During the most recent years of urbanization (2014-2015), the total numbers of benthic bacteria (TNB) increased significantly in the deepest part and were insignificantly higher in the shallow part in comparison to their number in the period of lower human activity in the catchment area (Fig. 4). The numbers of benthic sulfate reducing bacteria (SRB) were similar in both the deep and shallow parts of the lake, but comparing the study periods, their numbers were always higher during the period of urban land use (Tab. 6). As for seasonal fluctuations, the highest values of TNB and SRB were recorded in late summer-early autumn (Tab. 7).

The mineralization rates of sedimentary OC increased significantly in the urban period of land use (Fig. 4), with the highest rates in late summer-early autumn (Tab. 7). 
Table 5. Mean values \pm SD of organic carbon, sulfates and hydrogen sulfide and acid-soluble sulfides concentrations in the bottom sediment of Lake Gulbinas in August. Asterisks indicate significant differences in each chemical parameter between two study periods, urban and transitional (Tukey HSD test, $p \leq 0.05$ ).

\begin{tabular}{|c|c|c|c|c|}
\hline \multirow[t]{3}{*}{ Parameter } & \multirow[t]{3}{*}{ Sampling site } & \multicolumn{3}{|c|}{ Period, years } \\
\hline & & \multirow{2}{*}{$\begin{array}{l}\text { Transitional } \\
2001-2002\end{array}$} & \multicolumn{2}{|c|}{ Urban } \\
\hline & & & 2007 & 2014-2015 \\
\hline \multirow[t]{2}{*}{ Organic carbon (\% DW) } & Shallow part & $12.3 \pm 1.6$ & $12.0 \pm 1.0$ & $15.8 \pm 0.3^{*}$ \\
\hline & Deep part & $8.8 \pm 0.7$ & $12.0 \pm 0.5^{*}$ & $16.3 \pm 1.9^{*}$ \\
\hline \multirow[t]{2}{*}{ Sulfates $\left(\mathrm{mg} \mathrm{dm}^{-3}\right)$} & Shallow part & $33.7 \pm 2.2$ & $39.0 \pm 0.0$ & $36.6 \pm 1.3$ \\
\hline & Deep part & $28.9 \pm 3.0$ & $40.5 \pm 2.3^{*}$ & $36.0 \pm 0.2$ \\
\hline \multirow[t]{2}{*}{ Hydrogen sulfide $\left(\mathrm{mg} \mathrm{dm}^{-3}\right)$} & Shallow part & $112 \pm 16$ & $272 \pm 2^{*}$ & $260 \pm 14^{*}$ \\
\hline & Deep part & $164 \pm 4$ & $480 \pm 23^{*}$ & $524 \pm 44^{*}$ \\
\hline
\end{tabular}

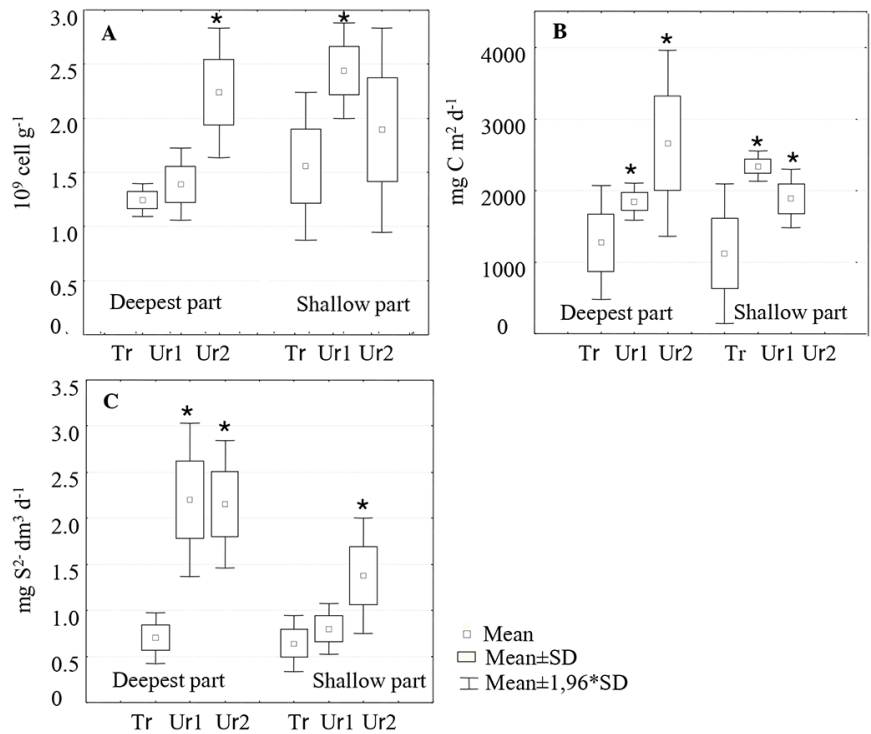

Fig. 4. Box plots of bacterial number (A), the rate of inorganic carbon emission (B) and sulfate reduction (C) in the bottom sediments of Lake Gulbinas in August during the transitional ( $\mathrm{Tr}-2001-2002)$ and urban (Ur1-2007 and Ur2-2014-2015) periods. Asterisks indicate significant differences in microbial parameters between study periods, urban and transition (Tukey HSD test, $p \leq 0.05$ ).

Throughout all study periods, anaerobic processes predominated in the sedimentary OC mineralization. The parallel measurements of oxygen-uptake showed that aerobic OC mineralization in the sediments of the deepest part of the lake was registered only in May $\left(122 \pm 20 \mathrm{mg} \mathrm{O}_{2} \mathrm{~m}^{2} \mathrm{~d}^{-1}\right)$ and contributed $2 \%$ of total OC mineralization. In August, in the shallow part of the lake, aerobic OC mineralization in the bottom sediments was greater during the transition period: $424 \pm 88$ in $2001-2002$ versus $288 \pm 52 \mathrm{mg} \mathrm{O}_{2} \mathrm{~m}^{2} \mathrm{~d}^{-1}$ in 2007 . During the most recent years of urbanization (2014-2015), this process was registered only in May and partly in September and made up $37 \%$ and $4 \%$ of total OC mineralization respectively (Tab. 7). Sulfate reduction, as an anaerobic terminal mineralization of $\mathrm{OC}$, was on average three times
Table 6. Benthic sulfate reducing bacteria number $\left(\mathrm{CFU} \mathrm{g}^{-1}\right)$ in Lake Gulbinas in August. Asterisks indicate significant differences in bacteria number between two study periods, urban and transitional (Tukey HSD test, $p \leq 0.05$ ).

\begin{tabular}{llll}
\hline Sampling site & \multicolumn{3}{c}{ Period, years } \\
\cline { 2 - 4 } \cline { 2 - 4 } & Transitional & \multicolumn{2}{c}{ Urban } \\
\hline Shallow part & $10^{2}$ & $10^{5^{*}}$ & $10^{6^{*}}$ \\
Deep part & $10^{2}$ & $10^{5^{*}}$ & $10^{6^{*}}$ \\
\hline
\end{tabular}

higher in the deepest part of the lake during active urban land use than in the years of the transitional period (Fig. 4), while in the shallow part this process reached its highest values $\left(1.8 \mathrm{mg} \mathrm{S}^{2-} / \mathrm{dm}^{3} \mathrm{~d}^{-1}\right)$ only in 2015 . The highest rates of SR in the bottom sediments of both parts of the lake were recorded in late summer (Tab. 7).

\section{Discussion}

Physicochemical characteristics (dissolved oxygen, temperature, nutrients) of the water in Lake Gulbinas revealed spatial and temporal variability over the last 50 years that is most probably related to changes in land use in the catchment area during the study periods. The ratio of the catchment vs lake areas indirectly indicates the importance of changes in the catchment for the functioning of the lake ecosystem (Kilkus and Bernatonis, 2003). Lake catchment area plays a crucial role in shaping the chemical composition of a lake's water, as other authors have also noted (e.g., Shadrin et al., 2016). Our study demonstrated a significant decrease of water transparency (on average from 2.0 in 1962 to $0.8 \mathrm{~m}$ in 2015), which is an indication of increased lake eutrophication (Kavaliauskienė, 1996). In May-September 1987 and 2007, mean Chl $a$ values reached 18.3 and $37 \mu \mathrm{gL}^{-1}$ respectively and the mean values of trophic state index (TSIChla) increased from 50 in 1987 to 65 in 2007 (Kavaliauskiene, 1996; Evolution of Ecological State..., 2007). According to Carlson (1977), such augmentation of the index shows the growing lake trophy from mesotrophic to hypereutrophic. 
Table 7. Seasonal fluctuations in the number of benthic bacteria and rates of microbial processes in the lake during the urban land use period (2014-2015, mean values $\pm \mathrm{SD}$ ). TNB, SRB, $R_{\text {aer, }} R_{\text {total }}$, SR are the benthic bacterial number, sulfate reducing bacteria number, oxygen consumption rate, total respiration rate of benthic community and sulfate reduction respectively.

\begin{tabular}{|c|c|c|c|c|c|}
\hline Sampling time & $\mathrm{TNB}, 10^{9}$ cells $/ \mathrm{g}^{-1}$ & $\mathrm{SRB}, \mathrm{CFU} / \mathrm{g}^{-1}$ & $R_{\text {aer }}, \mathrm{mg} \mathrm{O}_{2} / \mathrm{m}^{2} \mathrm{~d}^{-1}$ & $R_{\text {total }}, \mathrm{mg} \mathrm{C} / \mathrm{m}^{2} \mathrm{~d}^{-1}$ & $\begin{array}{l}\mathrm{SR}, \mathrm{mg} \\
\mathrm{S}^{2-} / \mathrm{dm}^{3} \mathrm{~d}\end{array}$ \\
\hline \multicolumn{6}{|l|}{ Shallow part } \\
\hline May & $1.7 \pm 0.7$ & $10^{4}-10^{6}$ & $966 \pm 186$ & $1142 \pm 362$ & $0.4 \pm 0.1$ \\
\hline August & $1.9 \pm 0.7$ & $10^{5}-10^{6}$ & 0 & $1887 \pm 147$ & $1.4 \pm 0.4$ \\
\hline September & $1.9 \pm 0.6$ & $10^{5}-10^{6}$ & $144 \pm 14$ & $1758 \pm 678$ & $0.9 \pm 0.1$ \\
\hline \multicolumn{6}{|l|}{ Deep part } \\
\hline May & $1.7 \pm 0.2$ & $10^{5}-10^{6}$ & $122 \pm 20$ & $2315 \pm 42$ & $0.6 \pm 0.1$ \\
\hline August & $2.9 \pm 0.6$ & $10^{6}-10^{6}$ & 0 & $2658 \pm 217$ & $2.1 \pm 0.2$ \\
\hline September & $2.3 \pm 0.2$ & $10^{6}-10^{6}$ & 0 & $2302 \pm 67$ & $1.2 \pm 0.4$ \\
\hline
\end{tabular}

Statistically significant increases of late spring-early autumn mean temperature values in the upper water layer of the lake from 1962 to the period 2007-2015 indicate a warming trend for the lake that might be influenced by global climatic warming. Presently, compared to the 20th century, the average annual temperature in Lithuania has increased by $0.7-0.9^{\circ} \mathrm{C}$ (Lithuanian hydrometeorological..., 2019). However, not only global warming, but also urbanization in the catchment area might affect the lake water temperature changes (Clapcott et al., 2012). While thermal summer stratification of the lake was observed even in 1962, the thermocline depth in the urban period has risen from $6-8 \mathrm{~m}$ to $3-5 \mathrm{~m}$ and the near bottom water temperature has insignificantly decreased. Despite insignificant differences in the oxygen concentration in the upper water layer throughout the study periods, a widening layer without oxygen was detected in the deepest part of the lake. This might be a result of the combined effects of eutrophication and increased temperatures, resulting in an expanding area of 'dead zone', as has been reported in eutrophied waters across the globe in other studies (Middelburg and Levin 2009; Marce et al., 2010; Jenny et al., 2016). The tendency of complete depletion of oxygen near the bottom throughout all sampling time has led to an accumulation of the end product of sulfate reduction hydrogen sulfide, the concentration of which increased gradually with depth, reaching its highest values near the bottom during the first years of the urban period.

Agriculture in catchments is usually highly related to nitrate export and its increased concentration in water streams (Johnson et al., 1997; Gergel et al., 2002). In the surface water layer of Lake Gulbinas, the highest contents not only of nitrogen, but also phosphorus were found at the end of agriculture period, this possibly relating to agricultural practices of the country. Obviously, these nutrients were introduced into the lake both from nearby agricultural areas and by the Rieše stream, which at that period flowed through fields with intensive agriculture, as earlier studies also noted (Kilkus, 1986). Several studies have showed increased phosphorus content in water streams with catchments that experienced an increase in urban lands (Allan, 2004; Castillo et al., 2012). However, in this study, both nitrogen and phosphorus concentrations in the upper water layer significantly decreased during urbanization compared with the agricultural period. Nevertheless, within the predominately urban land use period, despite decreasing TP values in the upper water layer, a significant increase in its concentration was registered in the near bottom waters compared to that observed at the end of agriculture. One of the most important factors affecting the TP concentration in lake water is its release from sediments, because sedimentary $\mathrm{P}$ can act as an internal load to the overlying water column for a long period (Sterner, 2008; Mehner et al., 2008; Wang and Liang, 2015). Such release from bottom sediment may have a significant impact on water quality and may result in continuing eutrophication for a considerable period, even following external load reduction (Granéli, 1999; Hou et al., 2013).

The growing trophic status of the lake suggests that there may be an increase in the amount of autochthonous OC in the sediments. On the other hand, the possibility of inputs of allochthonous OC to the lake with suspended solids from urban areas has increased. For example, in the summer of 2007, with intensive construction near the lake, the amount of suspended substances in the lake water reached an average of $11.2 \pm 2.3 \mathrm{mg} \mathrm{L}^{-1}$ versus $2.8 \pm 0.5 \mathrm{mg} \mathrm{L}^{-1}$ in the period of low human pressure in the catchment during the transition period (Taminskas et al., 2004). Meanwhile, in the Rieše stream above its inflow into the lake, the concentration of suspended substances was lower and made up $3.1 \pm$ $1.1 \mathrm{mg} \mathrm{L}^{-1}$. This suggests that suspended solids entered the lake not only through the stream, but also directly from construction sites near the steep shoreline. Similarly, the study of Castillo et al. (2012) noted that higher suspended solid concentrations, runoff and conductivity were observed in streams with higher rates of increase in urban lands in their catchment. Thus, besides eutrophication, other human influences during urbanization, such as erosion from construction sites, might have an impact on the environmental conditions and sedimentary organic matter accumulation in the lake. It is believed that the number of benthic bacteria is determined by the lake trophic level and higher numbers are recorded in eutrophic and hypertrophic lakes (Dzyuban, 2007). However, Kubera and Donderski (2017) noted that their number not always responded to lake productivity. The development of microorganisms in bottom sediments of water 
bodies primarily depends on the quality and availability of organic matter and also on surrounding environmental variables (Torres et al., 2011). In our study, the total number of benthic bacteria and the activity of the microbial community in the lake was higher during urbanization than in the period of lower human activity in the catchment area, indicating an increase not only in the quantity, but also in the availability of organic matter for benthic microorganisms during the intensive construction period along the shoreline. Microaerobic and anaerobic conditions near the bottom favored the predominance of anaerobic processes in OC mineralization in the both the deep and shallow parts of the lake with the highest activity of anaerobic microorganisms in summer. Only in May, during the spring mixing of the water, aerobic OC decomposition in the shallow part of the lake increased and constituted $37 \%$ of total OC mineralization. Rates of inorganic carbon emission from sediments reached higher values than those reported for most other medium-depth lakes of Lithuania (Krevš and Kučinskienè, 2012, 2018) and was comparable to values for eutrophic and hypereutrophic lakes in other regions (Dzyuban, 2007).

Sulfate reducing bacteria oxidize organic matter under anaerobic conditions using sulfate as terminal electron acceptors and producing sulfides. The amendment of sulfates in aquatic ecosystems results in an increase of acid volatile sulfides due to sulfate reduction and positively correlates with increasing diffusive phosphate fluxes (Chen et al., 2016). In both parts of Lake Gulbinas, the sulfate concentration insignificantly fluctuated between sampling periods. Despite this, in both parts of the lake, anaerobic mineralization of OC via sulfate reduction, as well as the amount of SRB during urbanization in the catchment, was significantly higher than in the years of the transitional period. Although sulfates have been identified as the limiting variable that influence sulfate reduction (Urban et al., 1994), our results suggest that the availability of OM probably controlled the rate of sulfate reduction in the surface layer of the bottom sediments in the studied lake. In other studies, it has also been noted that sulfate reduction is usually not limited by sulfate in surface layers (Holmer and Storkholm, 2001; Kosolapov et al., 2003). The activity of SRB in bottom sediments of aquatic ecosystems is also characterized by the distribution of a reduced sulfur amount. Significantly higher concentrations of hydrogen sulfide and acid soluble sulfides in the bottom sediments of both parts of the lake were observed during urbanization compared with that in the period of low human pressure in the catchment area. An increased concentration of sulfide may react or capture iron in sediments, thereby reducing phosphorus adsorption capacity and increasing its release (Li et al., 2016). The black silty bottom sediments in the deep part of the lake indicated the presence of FeS. The relevant inorganic forms of $\mathrm{P}$ in the sediment are ferric iron-bound and calciumbound phosphates and, during anoxia, phosphate is released from the Fe-bound pool (Boström et al., 1988; Heijs et al., 2000). A positive relation between released $P$ and elevated rates of sulfate reduction has been demonstrated (Smolders and Roelofs, 1993; Giordani et al., 1996; Roden and Edmonds, 1997). Studies conducted in mesophilic anaerobic digestion of sewage sludge showed that enhanced phosphate release was attributable to sulfate reduction to sulfide and the subsequent release of phosphate from ferric or ferrous phosphate
(Takashima, 2018). In our study, the anaerobic situation in the sediments is beneficial for the dissolution of $\mathrm{P}$ compounds and their concentration gradient provokes their diffusion to overlying water where they can be reused by photosynthetic organisms (Samarkin et al., 1992), This, in turn, may enhance the internal eutrophication of Lake Gulbinas.

Thus, our results showed that the elevated concentration of OC (autochthonous and allochthonous) in bottom sediments of Lake Gulbinas during the urbanization of the catchment area has influenced the activity of the benthic microbial community, which in turn has resulted in increased mineralization and depletion of oxygen. In the deep part of the lake, the predominance of anaerobic processes in OC mineralization, especially in summer, has expanded the layer without oxygen (from $8 \mathrm{~m}$ deep in 1962 to $3 \mathrm{~m}$ in 2014-2015) and has led to the accumulation of hydrogen sulfide near the bottom, the highest concentration of which was observed during the first years of active construction in the catchment and along the shoreline of the lake. In this period, the elevated rates of anaerobic OC mineralization via sulfate reduction led to the accumulation of a significantly higher content of sulfides in the surface layers of bottom sediments. A positive relationship between pools of sulfides and eutrophication has been correlated with the enhanced release of phosphorus from bottom to overlying water (Murray, 1995). Despite the fact that the TP concentration in the surface water has decreased since the agriculture period, its values were always more than three times higher near the bottom than in the upper water layer. Furthermore, a significant increase of TP concentration was registered in the near bottom waters during the urbanization period compared to that observed at the end of the period in which agriculture dominated in the catchment. The formation of black silty sediments in the deep part of the lake suggests the possibility of insoluble iron sulfide formation and, as it is known, this compound reduces the binding of phosphate iron oxides (Nürnberg, 1996; Kleeberg, 1997; Holmer and Storkholm, 2001) and thus a release of $P$ from sediments may enhance internal eutrophication of the lake.

In conclusion, the present study indicates that, first, during a period of active urbanization in the catchment and near the shoreline, a decrease of water transparency was observed in this small lake, especially in midsummer. Consequently, a reduction in the depth of the euphotic zone was also noted, along with an increase of the anoxic hypolimnion zone with reduced products such as $\mathrm{H}_{2} \mathrm{~S}$ in the water column of the deep part among the negative effects of anthropogenic eutrophication. Second, an increase in benthic organic matter processing was observed with a predominance of anaerobic processes that can stimulate the release of nutrients and reduced compounds and their recycling back to the water, this in turn having possible negative effects on the ecological conditions of the lake. This study, along with other research focusing on changes in ecological conditions in lakes due to changes in land use in the catchment, may be useful for designing proper mitigation measures to improve the ecological status of impacted small lakes, in particular for predicting and/or minimizing the impact on lakes ecosystems of urban activity in the catchment and along the shoreline.

Acknowledgements. This work was funded by the Lithuanian Ministry of Education and Science (IIMTEPP 2017-2021). 


\section{References}

Allan JD. 2004. Landscapes and riverscapes: the influence of land use on stream ecosystems. Annu Rev Ecol Evol Syst 35: 257-284.

Bazzanti M, Seminara M, Tamorri C. 1993. Eutrophication in a deep lake: depth distribution of profundal benthic communities as an indicator of environmental stress. Verh Internat Verein Limn 25: 784-789.

Boström B, Andersen JM, Fleischer S, Jansson M. 1988. Exchange of phosphorus across the sediment-water interface. Hydrobiologia 170: 229-244.

Carlson RE. 1977. A trophic state index for lakes. Limnol Oceanogr 22: 361-369.

Castillo MM, San José JJ, Montes RA, Aguirre R, Thielen D, Buendía C. 2012. Effects of land use changes on streams in terrestrialaquatic palm ecotones (Morichals) of the Orinoco lowlands. Fundam Appl Limnol 181: 113-127.

Chen M, Li XH, He YH, et al. 2016. Increasing sulfate concentrations result in higher sulfide production and phosphorous mobilization in a shallow eutrophic freshwater lake. Water Res 26: 94-104.

Clapcott JE, Collier KJ, Death RG, et al. 2012. Quantifying relationships between land-use gradients and structural and functional indicators of stream ecological integrity. Freshw Biol 57: 74-90.

Conley DJ, Paerl HW, Howarth RW, et al. 2009. Controlling eutrophication: nitrogen and phosphorus. Science 323: 1014-1015.

Correl DL. 1997. Buffer zones and water quality protection: General principles. In Haycock N, Burnt T, Goulding K, Pinay G, eds. Buffer Zones: Their processes and potential in water protection. Harpenden, UK: Quest Environmental, pp. 7-20.

Daubarienè J, Valiuškevičius G. 2009. Lake classifications used in Lithuania: system and employment possibilities. Geografija 45: $111-121$.

Dzyuban AN. 2007. Destruction of organic matter and methane cycle in the bottom sediments of inland waters. Inst. Limnology, Russ. Acad. Sci. Press, St. Petersburg. Abstract of Doctoral dissertation, $42 \mathrm{p}$.

Evaluation of ecological state and anthropogenic impact on Lake Gulbinas 2007. Scientific Reports. Institute of Botany, Lithuanian State Science and Studies Foundation, Nr G-53/07, Lithuania, 55 p.

Garunkštis A. 1988. Water Reserves of Lithuania. Mokslas. Vilnius, $200 \mathrm{p}$.

Gergel SE, Turner MG, Miller JR, Melack JM, Stanley EH. 2002. Landscape indicators of human impacts to riverine systems. Aquat Sci 64: 118-128.

Giordani G, Bartoli M, Cattadori M, Viaroli P. 1996. Sulphide release from anoxic sediments in relation to iron availability and organic matter recalcitrance and its effect on inorganic phosphorus recycling. Hydrobiologia 329: 211-222.

Granéli W. 1999. Internal phosphorus loading in Lake Ringsjön. Hydrobiologia 404: 19-26.

Heijs SK, Azzoni R, Giordani G, et al. 2000. Sulfide induced release of phosphate from sediments of coastal lagoons and the possible relation to the disappearance of Ruppia sp. Aquat Microb Ecol 23: $85-95$.

Holmer M, Storkholm P. 2001. Sulphate reduction and sulphur cycling in lake sediments: a review. Freshw Biol 46: 431-451.

Hou D, He J, Lü Ch, Sun Y, Zhang F, Otgonbayar K. 2013. Effects of environmental factors on nutrients release at sediment-water interface and assessment of trophic status for a typical shallow lake, Northwest China. Sci World J, 16 p.

Jenny JP, Francus P, Normandeau A, et al. 2016. Global spread of hypoxia in freshwater ecosystems during the last three centuries is caused by rising local human pressure. Glob Change Biol 22: $1481-1489$

Jeppesen E, Søndergaard M, Kronvang B, Jensen JP, Svendsen LM, Lauridsen TL. 1999. Lake and catchment management in Denmark. Hydrobiologia 395-396: 419-432.

Johnson LB, Richards C, Host GE, Arthur JW. 1997. Landscape influences on water chemistry in midwestern stream ecosystems. Freshw Biol 37: 193-208.

Kavaliauskienè J. 1996. Algae of Lithuanian Lakes. Vilnius. 173 p.

Kilkus K. 1986. Lithuanian reserves lakes. Vilnius; Mokslas, pp. 5055 .

Kilkus K, Bernatonis M. 2003. Thermics, oxygen regime and water conductivity of Lake Balsys and Gulbinas. Geografija 39: $10-15$.

Kilkus K. 2005. Limnology. Vilnius: VU Press, Lithuania. 271 pp.

Kleeberg A. 1997. Interactions between benthic phosphorus release and sulfur cycling in Lake Scharmützelsee (Germany). Water Air Soil Pollut 99: 391-399.

Klimkaitė I. 1963. Hydrochemistry of Riešè River basin Lakes. In: Bieliukas K, ed. Study of Lakes and Wetlands. Vilnius 15: 93-196.

Kosolapov DB, Rogozin DYu, Gladchenko IA, Kopylov AI, Zakharova EE. 2003. Microbial sulfate reduction in a brackish meromictic steppe Lake. Aquat Ecol 37: 215-226.

Krevš A, Kučinskienè A. 2012. Microbial decomposition of organic matter in the bottom sediments of small lakes of the urban landscape (Lithuania). Microbiology 81: 477-483.

Krevš A, Kučinskienè A. 2018. Microbial decomposition of sedimentary organic matter in small temperate lakes. Fundam Appl Limnol 191: 239-251.

Kubera $Ł$, Donderski W. 2017. Distribution and activity of benthic bacteria in four lakes in the Bory Tucholskie National Park (Poland). Aquat Microb Ecol 79: 127-135.

Kuznetsov SI, Dubinina GA. 1989. Methods of investigation of aquatic microorganisms. Moscow: Nauka, 285 p. (in Russian).

Lang C, Lods-Croset B. 1997. Oligochaetes versus chironomids as indicators of trophic state in two Swiss lakes recovering from europhication. Arch Hydrobiol 139: 187-195.

Li Z, Sheng Y, Yang J, Burton ED. 2016. Phosphorus release from coastal sediments: impacts of the oxidation-reduction potential and sulfide. Mar Pollut Bull 113: 176-181.

Linkeviciene R, Taminskas J, Simanauskiene R. 2004. The influence of the lake basin and the lakeside area on the evolution of organogenic littoral zone. Geogr Yearbook 37: 35-46.

Lithuanian Hydrometeorological Service under the Ministry of Environment, 2019

Mainstone CP, Parr W. 2002. Phosphorus in rivers - ecology and management. Sci Total Environ 282-283: 25-47.

Marce R, Rodriguez-Arias MA, Garcia JC, Armengol J. 2010. El Niño Southern Oscillation and climate trends impact reservoir water quality. Glob Change Biol 16: 2857-2865.

Margaritora FG, Bazzanti M, Ferrara O, Mastrantuono L, Seminara M, Vagaggini D. 2003. Classification of the ecological status of volcanic lakes in Central Italy. J Limnol 62: 49-59.

Margaritora FG, Fumanti B, Alfinito S, et al. 2005. Trophic condition of the volcanic Lake Nemi (Central Italy): environmental factors and planktonic communities in a changing environment. J Limnol 64: 119-128.

Megonigal JP, Hines ME, Visscher PT. 2004. Anaerobic metabolism: linkages to trace gases and aerobic processes. In: Schlesinger WH, ed. Biogeochemistry. Oxford, UK: Elsevier-Pergamon, 317-424.

Mehner T, Diekmann M, Gonsiorczyk T, et al. 2008. Rapid recovery from eutrophication of a stratified lake by disruption of internal nutrient load. Ecosystems 11: 1142-1156. 
Middelburg JJ, Levin L. 2009. Coastal hypoxia and sediment biogeochemistry. Biogeosciences 6: 1273-1293.

Moore JW, Schindler DE, Scheuerell MD, Smith D, Frodge J. 2003. Lake eutrophication at the urban fringe, Seattle region, USA. Ambio: 32: 8-13.

Murray TE. 1995. The correlation between iron sulfide precipitation and hypolimnetic phosphorus accumulation during one summer in a softwater lake. Can J Fish Aquat Sci 52: 1190-1194.

Nowlin WH, Evarts JL, Vanni MJ. 2005. Release rates and potential fates of nitrogen and phosphorus from sediments in a eutrophic reservoir. Freshw Biol 50: 301-322.

Nürnberg GK. 1996. Comment: Phosphorus budgets and stoichiometry during the open-water season in two unmanipulated lakes in the Experimental Lakes Area, northwestern Ontario. Can J Fish Aquat Sci 53: 1469-1471.

Porter K, Feig YS. 1980. The use of DAPI for identifying and counting aquatic microflora. Limn Oceanogr 25: 943-948.

Postgate JR. 1984. The sulfate reducing bacteria. 2nd edn. Cambridge Univ. Press, 208 pp.

Roden EE, Edmonds JW. 1997. Phosphate mobilization in iron-rich anaerobic sediments: microbial Fe(III) oxide reduction versus ironsulfide formation. Arch Hydrobiol 139: 347-378.

Rosenberg DM, Resh VH. 1993. Introduction to freshwater biomonitoring and benthic macroinvertebrates. In Rosenberg DM, Resh VH, eds. Freshwater biomonitoring and benthic macroinvertebrates. New York: Chapman/Hall, pp. 1-9.

Samarkin VA, Rivkina EM, Pachersky YaA. 1992. Biogeochemical processes in impoundments and their impact on water quality. In Degens ET, Kempe S, Lein AYu, Sorokin YuI, eds. Interactions of bigeochemical cycles in aquaeous ecosystems. Hamburg 7: 85-92.

Shadrin NV, EL-Shabrawy GM, Anufriieva EV, Goher ME, Ragab E. 2016. Long-term changes of physicochemical parameters and benthos in Lake Qarun (Egypt): can we make a correct forecast of ecosystem future? Knowl Manag Aquat Ecosyst 417: 18.
Smith VH. 2003. Eutrophication of freshwater and coastal marine ecosystems: a global problem. Environ Sci Pollut Res 10: 126-139.

Smolders A, Roelofs JGM. 1993. Sulphate-mediated iron limitation and eutrophication in aquatic ecosystems. Aquat Bot 46: 247-253.

Søndergaard M, Jeppesen E, Lauridsen TL, et al. 2007. Lake restoration: successes, failures and long-term effects. $J$ Appl Ecol 44: $1095-1105$.

Sorokin J. 1999. Aquatic microbial ecology. Backhaus Publishers. $247 \mathrm{p}$.

Sterner RW. 2008. On the phosphorus limitation paradigm for lakes. Int Rev Hydrobiol 93: 433-445.

Studies of Lithuanian lakes eutrophication and their development forecast. 1989. Scientific Reports. Department of Geography, Institute of Zoology and Parasitology, Lithuania. 266 p.

Takashima M. 2018 Enhanced phosphate release from anaerobically digested sludge through sulfate reduction. Waste Biomass Valoriz: $1-7$.

Taminskas J, Linkevičienė R, Šimanauskienė R. 2004. The influence of the use of lakes on the evolution of organogenic littoral zones. Geogr Yearbook 37: 47-53.

Torres IC, Inglett KS, Reddy KR. 2011. Heterotrophic microbial activity in lake sediments: effects of organic electron donors. Biogeochem 104: 165-181.

Urban NR, Brezonik PL, Baker LA, Sherman LA. 1994. Sulfate reduction and diffusion in sediments of little rock lake, Wiskonsin. Limn Oceanogr 39: 797-815.

Volkov II, Zhabina N. 1980. Methods for determination of various sulfur compounds in marine sediments. Moscow: Nauka. 216 p. (in Russian).

Wang L, Liang T. 2015. Distribution characteristics of phosphorus in the sediments and overlying water of Poyang Lake. PloS One 10: e0125859.

Yang X, Wu X, Hao H, He Z. 2008. Mechanisms and assessment of water eutrophication. J Zhejiang Univ Sci B 9: 197-209.

Cite this article as: Krevš A, Kučinskienè A, Manusadžianas L. 2019. Long-term changes of water physicochemical conditions and benthic microbial processes in a small lake associated with land use in the catchment. Knowl. Manag. Aquat. Ecosyst., $420,47$. 